\title{
AS PRERROGATIVAS DOS INSTITUTOS FEDERAIS E A OFERTA EDUCACIONAL
}

\author{
Carla Nogueira Patrão de Aquino ${ }^{1}$ \\ ORCID: https://orcid.org/0000-0002-0641-5990 \\ Ana Lúcia Mussi de Carvalho Campinho ${ }^{2}$ \\ ORCID:https://orcid.org/0000-0001-9728-9063
}

Ana Paula Serpa Nogueira de Arruda ${ }^{3}$

ORCID: https://orcid.org/0000-0001-7471-2367

Recebido em: 16/04/2021

Publicado em: 30/06/2021

\section{RESUMO}

O estudo tem, como objetivo, analisar a atuação do Instituto Federal Fluminense (IFFluminense) no Norte Fluminense (NF), um equipamento público de educação, ciência e tecnologia que traz, como missão, concorrer para o desenvolvimento local e regional. $\mathrm{O}$ recorte que se estabelece neste artigo, como um indicativo do "ir ao encontro" da sociedade como um vetor do desenvolvimento, é a oferta de formação técnica e tecnológica nos campi localizados nessa mesorregião. Assim, na escrita do artigo, apresenta-se, em linhas gerais, o pari passu da trajetória das instituições federais de educação profissional e tecnológica no contexto do crescimento brasileiro, com uma ênfase na constituição dos Institutos Federais e na expansão da Rede Federal, que proporcionou uma interiorização da oferta de formação. E,considerando a diversidade social e cultural e a diferenciação produtiva características dos municípios brasileiros, a exemplo do Norte Fluminense, pode-se falar também em vários interiores no interior do território brasileiro, caracterizados, muitas vezes, como núcleos urbanos que, contemplados com grandes investimentos, configuram-se, por um lado, como ilhas de prosperidade e, de outro, a periferia, os que se encontram fora do raio de alcance dos benefícios e que demandam ações em direções e sentidos diferentes, sendo esses territórios que dão sentido à presença de um Instituto Federal.

PALAVRAS-CHAVE: Educação Profissional e Tecnológica; Oferta de Formação; Instituto Federal; Desenvolvimento.

\section{THE PREROGATIVES OF THE FEDERAL INSTITUTES AND THE EDUCATIONAL OFFER}

\footnotetext{
${ }^{1}$ Assistente Social no Instituto Federal de Educação Ciência e Tecnologia Fluminense (IFFluminense) e Doutoranda do Programa de Pós-Graduação em Planejamento Regional e Gestão da Cidade da Universidade Cândido Mendes (UCAM).

${ }^{2}$ Doutoranda em Planejamento Regional e Gestão da Cidade pela Universidade Cândido Mendes (UCAMCampos). Mestra em Educação pela Universidade Federal Fluminense (UFF).

${ }^{3}$ Doutora em Sociologia Política pela Universidade Estadual do Norte Fluminense Darcy Ribeiro (PGPS/UENF) e professora do Programa de Pós-Graduação em Planejamento Regional e Gestão de Cidades na Universidade Cândido Mendes (UCAM).
} 


\begin{abstract}
The research has, as objective, to analyze the Federal FluminenseInstitute (IFFluminense) performance in the Northwestern Fluminense region (NF), an educational, scientifical and technological public equipmentwhich brings, as mission, concur to the local and regional development. The cutout stablished in this paper, as a sign of the "go to meet" of society as a vector of development, is the offering of technical and technological educationin the campusessituated in this mesoregion. Thus, in this article, it's present, in general lines, the paripassuof the way of the educational, scientifical and technological federal institutions in the context of Brazilian growth, with an emphasis in the Federal Institutes constitution and in the Federal Educational Network, which has provided an interiorization in the offering of education.And, considering the social, cultural and productive differentiation of Brazilian cities, withNorthwestern Fluminense region as example, it's discussed about the variety of interior areasin the interior of Brazilian territory, characterized, many times, as urban centers which, contemplated with large investments, are configurated, on one hand, as prosperity island, and, in another hand, the periphery, the ones who are found out of the range of benefits and which demand actions in different directions and ways. These territories give meaning to the presence of a Federal Institute.
\end{abstract}

KEYWORDS: Professional and Technological Education; Educational Offering; Federal Institute; Development.

\title{
INTRODUÇÃO
}

Falar em criação dos Institutos Federais (IFs), de um novo desenho de instituição, parece contraditório quando recorremos auma evolução de uma instituição federal destinada à educação profissional e tecnológica, num decurso de mais de um século, o que pode sugerir uma continuidade e não uma nova institucionalidade que surge. Nesse sentido, se é verdade que, em sua missão atual,existe uma característica nuclear, a educação profissional, científica e tecnológica, essa finalidade vem revestida de uma proposta de educação que vai ao encontro das pessoas, de seus saberes e necessidades, das potencialidades locais, para atuar como partícipe do desenvolvimento de uma região.

A implantação de campus de um IF, em um território, precisa ser compreendida como um movimento de forças no sentido do desenvolvimento regional e local e de pertencimento, o que dá razão à sua singularidade, traduzida nos objetivos dessas instituições. Portanto entender a interiorização dos IFs é também interiorizar a dimensão de seu alcance, é perceber a verticalização como uma medida de pertencimento ao local, pois permite que a instituição alcance os brasileiros desde os trabalhadores menos favorecidos e destituídos de direitos sociais até os jovens que optam por avançar em níveis mais elevados da educação; é compreender a dimensão da autonomia que lhe é conferida para a construção de seu projeto 
pedagógico; é entender o princípio básico do ensino articulado à pesquisa aplicada e à extensão.

Poderíamos ousar com a hipótese de que a expansão dos IFs faz parte de um projeto de educação de base "invertida", o que significa uma formação científica e tecnológica em que o aspecto econômico sobrepuje o humano, mas que o considere; uma formação profissional e tecnológica numa perspectiva do fortalecimento da região e de sua população, de sua capacidade de articulação política e gerenciamento de suas riquezas. Nesse sentido, os IFs cumprem o seu compromisso com a cidadania.

Entendemos que a avaliação de um projeto dessa amplitude requer médio e longo prazo, e a criação dessas instituições tem uma história recente de pouco mais de uma década e ainda em aberto, o que não nos permite uma ideia conclusiva, mas apenas discutir alguns aspectos que poderiam ser trazidos para o debate. $\mathrm{O}$ recorte que estabelecemos para a discussão a respeito do movimento do Instituto Federal de Educação Ciência e Tecnologia Fluminense (IFFluminense) na mesorregião Norte Fluminense (NF) como um indicativo desse "ir ao encontro" da sociedade, como um vetor do desenvolvimento a partir da análise da oferta de formação; é também um convite para outras leituras sobre essa política de educação profissional e tecnológica (ETP) de alcance escalar.

\section{AS INSTITUIÇÕES FEDERAIS DE EDUCAÇÃO PROFISSIONALPARI PASSU COM O CRESCIMENTO DO PAÍS, NUM DECURSO HISTÓRICO}

Os IFs surgem, como uma nova institucionalidade, a partir da Lei $\mathrm{n}^{\circ} 11.892$, de 29 de dezembro de 2008, que cria a Rede Federal de Educação Profissional, Científica e Tecnológica (Rede Federal),dentro das políticas públicas para a interiorização da EPT e do ensino superior no país. Três dimensões pautam essa expansão da educação profissional, científica e tecnológica: a dimensão geográfica, a social e a dimensão desenvolvimento e, dentro delas, vários fatores foram considerados como prioritários.

Na dimensão geográfica, temos: i) a interiorização da oferta pública da educação profissional e do ensino superior ii) a universalização do atendimento das mesorregiões brasileiras; iii) o atendimento a municípios em microrregiões não atendidas por escolas federais; iv) o atendimento prioritário amunicípios com mais de 50 mil habitantesou microrregiões não atendidas; e v) a oferta da educação superior federal para o estado abaixo da média nacional. 
A dimensão social justifica: i) a universalização de atendimento aos territórios de cidadania; ii) o atendimento a municípios com percentual elevado de extrema pobreza; e iii) o atendimento a municípios populosos com baixa receita per capita, integrantes do G100. No tocante à dimensão desenvolvimento: i) o atendimento a municípios com Arranjos Produtivos Locais (APLs); e ii) o entorno de grandes investimentos.

Mesmo já desenvolvendo, de forma assistemática, projetos junto às populações vulneráveis, às prefeituras, às empresas locais, as instituições federais tiveram suas finalidades ampliadas com a criação dos Institutos Federais. A partir da relação educação, ciência e tecnologia, os Institutos, segundo a legislação, passam a ter que:

\begin{abstract}
Orientar sua oferta formativa em benefício da consolidação e fortalecimento dos arranjos produtivos, sociais e culturais locais [...]; constituir-se em centro de excelência na oferta do ensino de ciências [...]; qualificar-se como centro de referência no apoio à oferta do ensino de ciências nas instituições públicas de ensino [...]; desenvolver programas de extensão e de divulgação científica e tecnológica; realizar e estimular a pesquisa aplicada, a produção cultural, o empreendedorismo, o cooperativismo e o desenvolvimento científico e tecnológico; [...] promover a produção, o desenvolvimento e a transferência de tecnologias sociais [...]. (BRASIL, 2008b).
\end{abstract}

Nos registros das transformaçõesda amplitude dessas escolas, é possível fazer uma leitura das etapas por que passou o país em seu processode desenvolvimento, no século XX, pela correspondência temporal e pela ofertada formação profissional, técnica e tecnológica e até mesmo retratada pela titulação que lhe foi atribuída a cada tempo. Em se tratando da educação profissional, grosso modo, a percepção é, pois, de uma relação direta com a questão do desenvolvimento e da necessidade de trabalhadores, que termina por reforçar a concepção de uma escola dual,sendo as Escolas de Aprendizes Artífices (EAA) destinadas às camadas populares, aos filhos dos trabalhadores.Desde a criação dessas instituições, evidencia-se o seu aspecto ideológico como formadoras de mão de obra dos filhos da classe trabalhadora, abarcando também a perspectiva de contenção e dedisciplinarização de potenciais infratores por parte desses jovens, num período de país recém-saído da escravatura e onde a industrialização era ainda incipiente.

No decorrer do século XX, à medida que o país altera a sua matriz produtiva, as EAAforam-se transformando para responder ànecessidade de mão de obra do país, no bojo do avanço do capitalismo e dos ditames do capital. Assim, pelo Decreto $\mathrm{n}^{\circ} 4.073$, de 30 de janeiro de 1942, as EAA transformaram-se em EscolasTécnicas Industriais,com formação 
profissional em articulação ao ensino propedêutico, momento em que o Brasil já transitava na direção da industrialização ${ }^{4}$. E, pela mesma razão, no governo Juscelino Kubitschek, dentro de um projeto desenvolvimentista e de forte investimento na industrialização do país (o conhecido Plano de Metas "50 anos em 5"), as Escolas Técnicas Industriais transformaramseem Escolas Técnicas Federais (ETF) pela Lei $\mathrm{n}^{\circ}$ 3.552, de 16 de fevereiro de 1959, conferindo-lhes "[...] personalidade jurídica própria e autonomia didática, administrativa, técnica e financeira". Na primeira lei da educação nacional, a Lei de Diretrizes de Bases nº.024, de 20 de dezembro de 1961, o Art.47 é dedicado ao ensino técnico,oficializando,assim, a formação para o trabalho.

Esse processo continua no período da Ditadura Militar e, em 1978, período de grande crescimento do país, três dessas escolas, localizadas nos centros industriais do país (São Paulo, Rio de Janeiro e Minas Gerais) são transformadas em Centros Federais de Educação Profissional e Tecnológica $\left(\mathrm{CEFETs}^{5}\right)$, passando a oferecer cursos superiores de tecnologia,num contexto econômico da chamada "marcha forçada", caracterizado por elevadas taxas de crescimento, no âmbito do II Plano Nacional de Desenvolvimento, com expressivos investimentos nos setores de energia, de infraestrutura e de insumos industriais básicos.

A estagnação da economia brasileira, na década de 1980,concorreu para que a transformação de outras ETFs emCEFETs não se ampliasse como o esperado e, até o final da década de 1990, apenas as escolas técnicas federais do Maranhão e da Bahia foram transformadas em CEFETs.

A década de 1990 foi singular e de dificuldades para as ETFse CEFETs. A opção do Governo Fernando Henrique Cardoso por uma política neoliberal, que se pauta pelo Estado mínimo e pelas privatizações, respingaramtambém nas políticas para a educação profissional e tecnológica, impondo mudanças significativas para essas escolas em sua função social.

Uma sucessão de medidas para redução de gastos e a submissão do país aos acordos internacionais, uma“aparelhagem estatal" ditada por organismos internacionais, a exemplo do Banco Interamericano de Desenvolvimento (BID), interferiram na oferta de cursos das ETFs,

\footnotetext{
${ }^{4}$ Como escolas técnicas, foram equiparadas às escolas de Ensino Médio e Secundário, possibilitando o prosseguimento de estudos na mesma área da educação profissional em nível secundário, sem, contudo, possibilitar o acesso ao ensino superior.

${ }^{5}$ A transformação em CEFETs estendia aos cursos superiores a parte aplicada e operacional dos cursos técnicos, formando, assim, engenheiros operacionais e industriais, demanda que se pressupunha necessária ao aprofundamento da industrialização do país. A política de desenvolvimento e a crença na manutenção das taxas de crescimento econômico levou a essa "explosão da demanda por mão de obra qualificada", e a Lei ${ }^{\circ}$ 5.692/1971 retrata esse momento, ao tornar compulsória a formação de técnicos para todo o $2^{\circ}$ Grau (ensino médio), decisão extremada, revista uma década depois com a publicação da Lei nº 7.044/1982.
} 
sob os princípios da Lei de Diretrizes e Bases da Educação Nacionalnº 9.394/1996 e do Decreto $n^{\circ}$ 2.208/1997. Nesse ideário, a proibição do ensino integrado (o que reúne o ensino médio e o ensino técnico na mesma matriz), uma singularidade das ETFs, soava como um instrumento de fortalecimento da iniciativa privada e de outros centros de formação profissional, a exemplo do Sistema $S^{6}$, instaurando uma certa fragilidade na missão social dessas instituições com a formação para o trabalho, o que, mais uma vez, retira oportunidades das camadas populares.

Com a Lei $\mathrm{n}^{\circ}$ 8.948, de 8 de dezembro de 1994, é criada o Sistema Nacional de Educação Tecnológica, e dá-se encaminhamentopara o processo de transformação de todas as ETFsem CEFETs, abrindo possibilidade para que as Escolas Agrotécnicas Federais também pleiteassem semelhante institucionalidade. Aedição da Lei nº.649/1998, em seu Art. 47, altera o Art. $3^{\circ}$ da Lei $n^{\circ} 8.948 / 1994$ e proíbe a expansão da oferta da educação profissional, por meio da criação de novas unidadesna esfera da gestão e do financiamento pela União, definindo que isso só poderia ocorrer "[...] em parceria com Estados, Municípios, Distrito Federal, setor produtivo ou organizações não-governamentais, que serão responsáveis pela manutenção e gestão dos novos estabelecimentos de ensino" (BRASIL, 1998), promulgada como medida determinante para a implantação do Programa de Expansão da Educação Profissional (Proep), financiado, em parte pelo BID, cujas condições estabelecidas sãodeterminantes para a natureza privatista dessa política.

A decisão de recorrer ao BID reforça o entendimento de que a Reforma da Educação Profissional, por meio do Proep, só se viabilizou após a ação do governo em relação à legislação educacional, segundo as determinações estabelecidas pelo Banco enquanto condição necessária para acesso aos recursos e com vistas a assegurar a implantação da reforma. (PEREIRA,2020, p. 212).

Apesar das restrições impostas à Rede Federal pelo Proep, no ano de 1999, as escolas reconquistam, junto ao Governo Federal, o direito de serem transformadas em CEFETs, com autonomia para oferta de cursos em diferentes níveis de formação técnica e tecnológica e, em seguida, nas licenciaturas das áreas das ciências exatas e com o desenvolvimento de ações

\footnotetext{
${ }^{6} \mathrm{O}$ Sistema S inclui: o Serviço Nacional de Aprendizagem Industrial (SENAI), o Serviço Nacional de Aprendizagem Comercial (SENAC), o Serviço Nacional de Aprendizagem Rural (SENAR) e o Serviço Nacional de Aprendizagem do Transporte (SENAT), instituições sob a gestão do setor privado, mas com recursos públicos, constituídos a partir da taxação dos trabalhadores dos respectivos setores. No entanto, além dessas instituições, a oferta da formação ocorre nas escolas técnicas privadas, nas empresas, em sindicatos, em associações comunitárias, em agências de ensino profissional livre, dentre outros.
} 
para a melhoria da educação básica.No entanto os passos mais significativos, no viés das políticas públicas para a expansão da educação profissional técnica e tecnológica ocorreram a partir de 2003, com governos mais progressistas e suas políticas de inclusão e de educação pública de formação profissional e de ensino superior que culminam com a promulgação da Lei n ${ }^{\circ}$ 11.892/2008, de criação da Rede Federal e dos Institutos Federais de Educação, Ciência e Tecnologia (IF).

Segundo Aquino (2020), há uma diferença entre os CEFETs e os Institutos Federais. Nos primeiros, o alinhamento era com a política desenvolvimentista, tanto em 1978, com a criação dos primeiros CEFETs, cujo objetivo era prover o País de mão de obra necessária para produzir bens de capital; como no final dos anos 1990, em que o objetivo era ainda fornecer mão de obra, mas agora sob o efeito da globalização, na perspectiva de país que se inseria na ordem global como um país periférico. Já o alinhamento dos Institutos Federais é com uma política de desenvolvimento centrada no território,

[...] condição dada pela sua estatura jurídica, com uma estrutura multicampi e uma autonomia atribuída por lei, que lhe possibilita estar no território não para executar políticas top-down, mas para agir (enfeixando as políticas públicas no território - intersetorialidade) em nome da transformação social do espaço. (AQUINO, 2020, p.18).

Nessa reestruturação das instituições federais de educação profissional e tecnológica, dinamizada pelo plano de expansão, essas instituições foram impelidas, em meio a resistências e disputas, a sair da zona de conforto, historicamente atribuída como o lugar da formação técnica. Háuma nova identidade ancorada numa história centenária, uma transição institucional que não acontece de forma automática, que precisa ser construída no dia a dia pelos gestores, pela comunidade acadêmica, pela comunidade externa e pelas representações da sociedade civil que com elas dialogam.

\section{A CONSTITUIÇÃO dOS INSTITUTOS FEDERAIS E A EXPANSÃO DA REDE FEDERAL}

A trajetória da expansão da Rede Federal opôs-se à lógica da localização concentrada e metropolizada da ocupação humana e econômica do território brasileiro e foi mais em direção às regiões interioranas e periféricas. Por isso, a criação de novos campi não é apenas uma decisão numérica; ela carrega uma intenção política, “[...] uma visão desenvolvimentista fundada na diminuição das desigualdades regionais.” (SANTOS, 2018, p. 119). 
Na Figura 1, sob forma de linha do tempo, mostra-se o conjunto de documentos e leis que fundamentaram, mesmo antes de seu início, a expansão e que legitimou a política de criação dos Institutos Federais, o que traz uma visão geral da complexidade para a implementação de uma política pública.

Figura 1 - Linha do tempo dos dispositivos legais fundantes do Programa de Expansão da Rede Federal de Educação Profissional e Tecnológica e da criação dos Institutos Federais

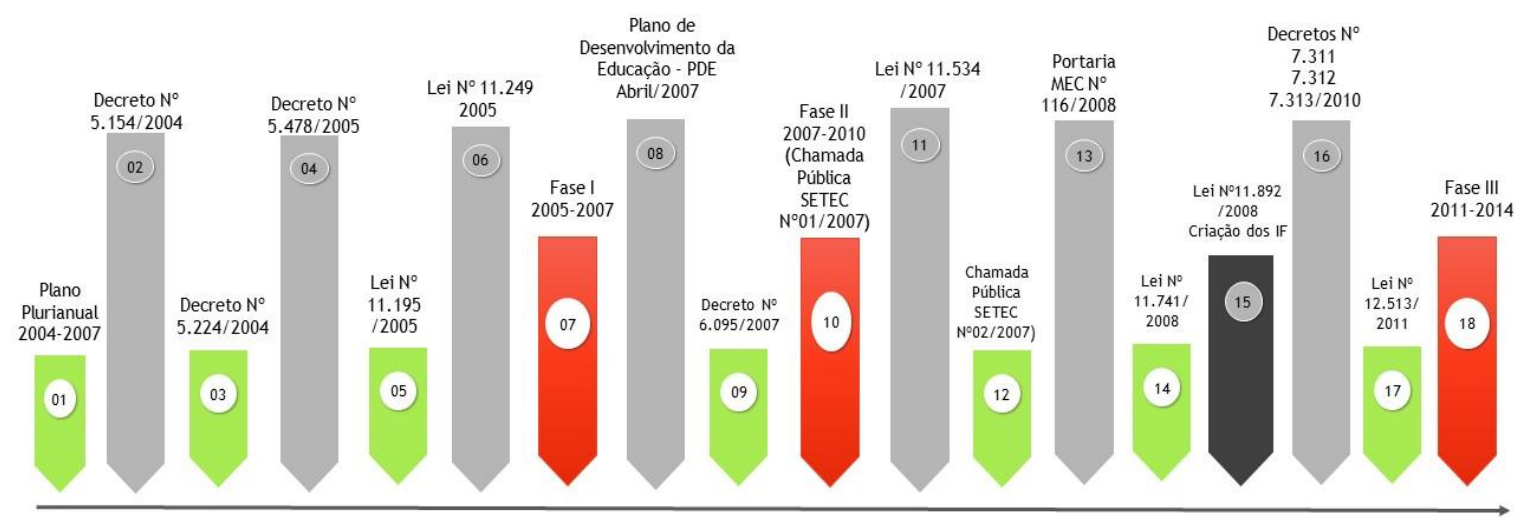

Fonte: Aquino (2020).

Importante ressaltar que a distribuição mais igualitária desse equipamento educacional pelo território, por cidades interioranas, multiplica as possibilidades de uma atuação em rede, interna e externamente.Em um país heterogêneo, diversificado e desigual como o Brasil, como afirma Bacelar (2013), essa presença da Rede em regiões interioranas pode contribuir, articulada com outras políticas públicas, no longo prazo, para alterar,de forma significativa,o quadro de desigualdades regionais.

O processo de interiorização dos IFsfoi um traço marcante na expansão, que permitiu o acesso de segmentos historicamente excluídos tanto da formação técnica como da formação superior e a expansão das funções institucionais.Ainda no campo de atuação, os IFs assumem a função de serem instituições acreditadoras e certificadoras de competências profissionais, com o objetivo de elevação de escolaridade dos trabalhadores, com prerrogativa de oferecer programas de certificação de saberes adquiridos na experiência de vida e de trabalho dos trabalhadores jovens e adultos; e acreditadoras, pela autonomia de atribuir crédito a outras instituições de educação profissional de poderem avaliar e certificar saberes laborais.

Também reafirma o compromisso com a formação de professores e com o desenvolvimento de ações para a melhoria da educação básica, dentro de um projeto político que defende o direito à educação e de igualdade de condições a todos, como prevê a 
Constituição Brasileira de 1988, associando os pilares educação-ciência-tecnologia- trabalhocultura, com o desafio perene de prepará-los para o exercício da cidadania profissional.

Isso, porém, não significa que essas oportunidades chegam aos segmentos populacionais mais excluídos de forma plena; há muito a ser aprimorado nos instrumentos de seleção, na oferta de cursos, principalmente para atender a segmentos que, por necessidade, veem, na educação profissional, a oportunidade de antecipar a inserção no mercado de trabalho e, com isso, alterar a composição da renda das respectivas famílias.Da mesma forma, a população cuja trajetória de vida não permitiu a permanência na escola ou mesmo o acesso a ela procura a educação de jovens e adultos, sob o formato do Programa Nacional de Integração da Educação Profissional com a Educação Básica - na Modalidade de Educação de Jovens e Adultos (Proeja)- por reconhecerem o conhecimento escolarimportante para suas vidas.Também a destacar, na perspectiva de formação dos trabalhadores, os IFpassam a ser instituições acreditadoras e certificadoras de competências profissionais ${ }^{7}$.

É evidente que as contradições em relação à educação/trabalho permanecem pulsando nas instituições, ou seja, priorizar os projetos de formação que atendem ao sistema hegemônico, do mercado, ou priorizar outras formas de organização do trabalho mais autônomas e democráticas, dentro de uma concepção de organização dos trabalhadores na direção de uma democracia participativa, de efetividade do direito à cidadania ${ }^{8}$.

\section{EDUCAÇÃO E DESENVOLVIMENTO NUMA AÇÃO DINÂMICA PARA A TRANSFORMAÇÃO NO TERRITÓRIO}

Geralmente é apreendido, no senso comum, que há uma linearidade na relação entreeducação e desenvolvimento. Entretanto, do ponto de vista das Ciências Sociais, trata-se de uma relação, uma vez que significa uma construção política-histórica. No caso da educação profissional, essa percepção estreita é a mais corrente, no entanto ela precisa ser relativizada.

\footnotetext{
${ }^{7}$ Certificadoras, pela prerrogativa de oferecer gratuitamente aos trabalhadores os processos de certificação de saberes adquiridos na experiência de vida e de trabalho dos trabalhadores jovens e adultos; e acreditadoras, pela autonomia de atribuir crédito a outras instituições de educação profissional poderem avaliar e certificar saberes laborais.

${ }^{8}$ Frigotto e Ciavatta (2003), emEducar o trabalhador cidadão produtivo ou o ser humano emancipado?,incentivam o debate que envolve a questão do acesso ao trabalho e à cidadania. Os autores defendem a tese de que o conceito de cidadania tem sido mal colocado e consideram que, no Brasil,a cidadania não está relacionada aos direitos civis, mas aos direitos econômicos e defendem duas dimensões fundamentais na cidadania: a liberdade e a igualdade, na perspectiva da polis grega, referindo-se a uma concepção que resgata o indivíduo como parte do coletivo.
} 
É verdade que a educação é condição sinequa non no processo de desenvolvimento. Também é verdade que vivemos emuma sociedade globalizada, o que, ao contrário do que parte dos seus apologistas propugnaram, acentuouassimetrias econômicas, políticas, sociais e culturais entre regiões e países centrais, semiperiféricos e periféricos, uma sociedade em que o conhecimento é poder. O que surpreende é, por um lado, uma concentração das decisões geoeconômicas e geopolíticas nos países centrais, e, por outro lado, a maioria dos países ainda numa posição de periféricos e semiperiféricos, sem que haja um movimento mais efetivo para reverter o cenário de desigualdades extremasaque submetem as populações.

Nesse sentido, a questão de base, ao tratar da relação entre educação e desenvolvimento nos IFs, é que é necessário pautar que conceito de educação e para qual modelo de desenvolvimento essas instituições foram criadas. Ou ainda: de que desenvolvimento se está falando? Bastaria a sua ação reservada ao espaço interno da inclusão produtiva por meio da formação de trabalhadores, ou sedeveria quebrar esses limites, somando-se à sociedade civil, na discussão de um projeto de desenvolvimento e de fomento a empreendimentos solidários e de médio e pequeno porte? O que pensa o trabalhador? A que aspira a sociedade?

Essas questões- cujas respostas despontam como uma agenda de pesquisa e reflexão levam-nos à tentativa de identificar a representação social dessas instituiçõese de que forma sua nova institucionalidade, a de Instituto Federal, vem ganhando representatividade no território, ou seja, como agente do desenvolvimento local e regional, uma vez que, historicamente, a representação social foi forjada na perspectiva da preparação para a indústria brasileira, dentro da concepção de outro modelo de desenvolvimento, tema que mereceria um outro estudo.

Cabe ressaltar que as representações sociais são construídas pelos e nos grupos sociais, coletivamente, em que o olhar de um, somado à percepção de outros, a partir de um mesmo estímulo, produzem pontos de intersecção reveladores das representações do grupo sobre determinado objeto. Moscovici (2012, p.72) afirma que a representação social é resultado da relação entre os sujeitos e o objeto da representação, sendo que o aspecto figurativo e o simbólico revelam os sentidos dessa representação. Portanto conhecê-los possibilita uma aproximação à identidade sociocultural do grupo em suas interrelações, conflitos e consensos, o que interfere no movimento cognitivo e psicossocial de assimilação e de produção coletiva de respostas para seus desafios.

Em suma, essa mudança traz os IFs para se colocarem em favor de um desenvolvimento socioeconômico fundamentado no princípio da política pública, voltado 
para responder a questões que fortaleçam a cidadania e promovam a justiça social, uma concepção de educação e de desenvolvimento com centralidade na inclusão, reunindo elementos convergentes da questão social e do desenvolvimento humano. Ao colocar em destaque a relação dos IFs com o desenvolvimento regional, algumas prerrogativas atribuídas por lei podem encorajar o debate. Nessa perspectiva, destacamosos aspectos: i) atuar em iniciativas que concorram para a educação de qualidade e para a valorização do professor, como capacitação técnica e atualização pedagógica dos docentes das redes públicas de ensino, com parcerias com as redes de ensino, com o poder público e com organizações de classe, potencializando suas ações; ii)ser agentes, promotores e participantes de ações multiinstitucionais, planejadas e articuladas com outras políticas, a exemplo daquelas de cunho social, o que possibilita a essas instituições potencializarem suas múltiplas alternativas ao desenvolvimento; iii) valer-se de sua autonomia para tecer diálogos e articulações com os diversos segmentos presentes no território.

A respeito desse último aspecto, tomamos de Santos (1996) o posicionamento, ao referir-se às universidades pautadas na ciência pós-moderna, no que setrata da autonomia institucional como algo a ser reivindicado pela própria academia. Para o autor, como comunidades universitárias, devem eliminar as hierarquias entre professores, estudantes e funcionários, reflexo da sociedade de classesa fim de "[...] superar as usuais interações em que os cidadãos são sempre forçados a renunciar à interpretação da realidade social que lhes diz respeito.”(SANTOS, 1996, p. 224). Nesse sentido, é papel político das instituiçõesirem ao encontro do desenvolvimento que valoriza e fortalece a sustentabilidade da vida dos cidadãos em suas múltiplas relações, considerando o direito à efetiva participação.

A metáfora do pêndulo ${ }^{9}$ pode traduzir, com mais clareza,a complexidade dessa relação de embates que são próprios do sistema capitalista: de um lado, a defesa de um projeto de desenvolvimento que considere as múltiplas dimensões humanas e, portanto, uma educação no âmbito da política pública como direito dos sujeitossociais; e,de outro,a que defende um projeto de desenvolvimento como sinônimo de crescimento econômico, que prioriza a esfera do econômico em detrimento das outras dimensões humanas. Portanto, de um lado, a prioridade são os sujeitos históricos e suas necessidades sociais e humanas, valores éticos-políticos, conteúdo histórico-científico, bem-estar, geração sustentável de conhecimento e de cidadania; e, de outro, produção da riqueza nacional, exploração do

\footnotetext{
${ }^{9}$ Usada por Otávio Ianni (1971), quando caracterizou o movimento de forças brasileiras entre um projeto de desenvolvimento nacional próprio, autônomo e soberano em relação às nações e outro, que defendia um projeto de desenvolvimento associado e dependente do grande capital.
} 
trabalhador, acumulação, processos produtivos complexos, rompimento de limites territoriais (regionais e nacionais), racionalidade econômica e indivíduos. A Figura 2 busca apresentar, de forma resumida, a relação entre educação e desenvolvimento. Os autores deste artigo concordam que a possibilidade de alterar o sentido dos vetores educação e desenvolvimento para alcançar um homem tecnicamente competente e civilmente crítico se dá pela via da política pública.

Figura 2 - A complexidade da relação educação e desenvolvimento

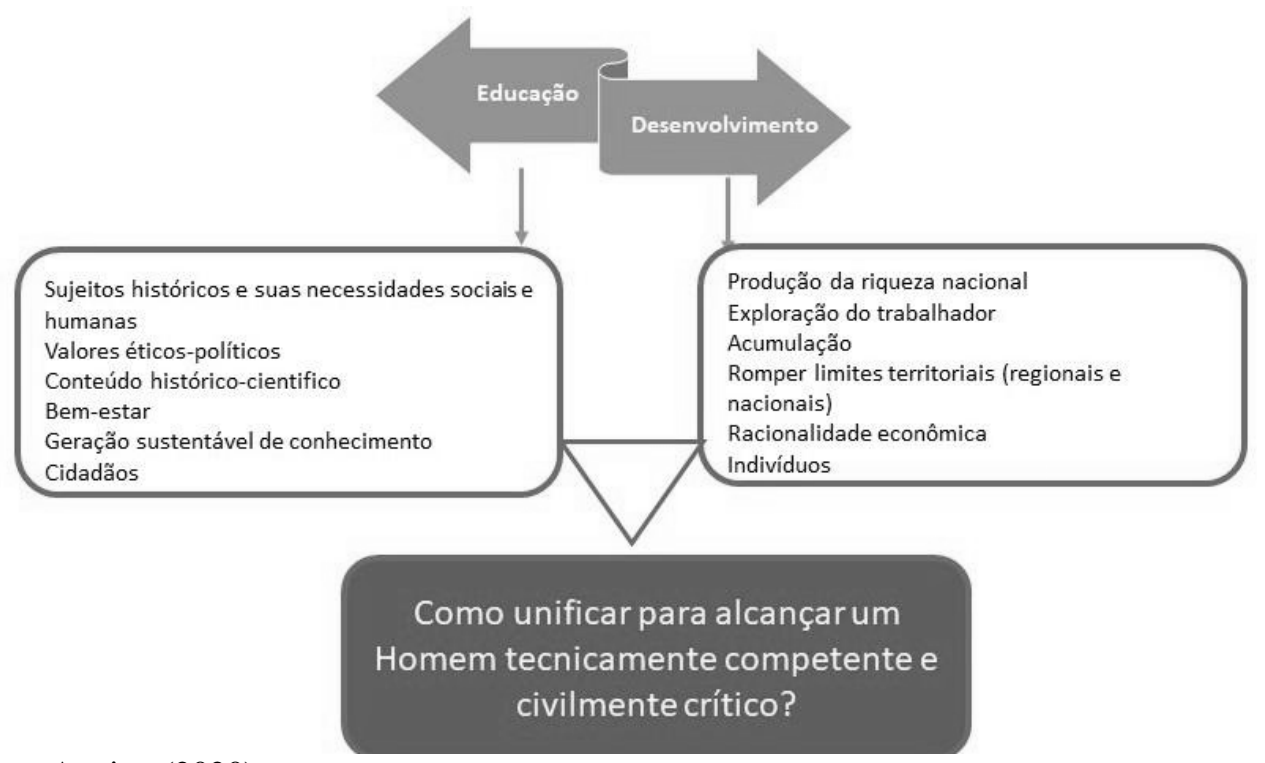

Fonte: Aquino (2020).

A educação, como eixo do desenvolvimento, sempre se pautou pela "vinculação estreita com o mundo da produção", na qual as necessidades do desenvolvimento partem das demandas dos agentes primordiais do poder econômico: os empresários capitalistas. Em decorrência, "[...] a educação, a ciência e a tecnologia aparecem, então, instrumentalmente subordinadas como condições para conseguir a competitividade.” (CORAGGIO, 2000a, p. 107-109).

Na realidade, a forma capitalista das relações sociais configura um sistema que tende, cada vez mais, a ser excludente e propenso a constantes crises, fato que não pode ser mais negado, mesmo por seus beneficiários.

Para Mészáros (2009), a crise estrutural do capitalismo atual vai-se aprofundar cada vez mais, alcançando não só a esfera socioeconômica, mas também todas as dimensões da sociedade. Nessa mesma perspectiva, Fontes (2005, p. 32) diz que o “[...] capitalismo perdeu a capacidade de aprofundar sua lógica e funciona como uma máquina de exclusão, condenando uma parcela da população a uma espécie de degredo mercantil”. 
Na perspectiva apresentada por Coraggio (2000c), é necessária a reconstrução de outros parâmetros de bem-estar, no sentido de suprir as necessidades humanas fundamentais e a melhoria estrutural, em que a reprodução ampliada seja da vida e não do capital. Dessa forma, o distanciamento e, muitas vezes, a oposição na relação educação e desenvolvimento devem ser superados, como também a separação entre políticas sociais e políticas econômicas.

É imprescindível, portanto, criar sinergias e mediações entre os governos, os sistemas políticos, o poder econômico e a sociedade civil, buscando, como ponto nuclear, o homem em todas as suas dimensões, em torno do qual orbitam o significado de desenvolvimento, de ciência e tecnologia, dos modelos econômicos e da irradiação da cultura.

A cisão engenheirada pela produção industrial entre o saber e o fazer, reservando a poucos o domínio das ciências e à classe trabalhadora, apenas a execução, tem, nas escolas profissionalizantes, a expressão mais visível desse pensamento dicotômico que alcança os processos formativos. Frigotto, Ciavatta e Ramos (2008) apontam a necessidade da educação de qualidade (básica articulada com a profissional) como condição para se chegar ao sujeito em todas as dimensões da vida e como as relações de poder e de força entre centro-periferia condicionam o acesso à educação de qualidade.

Nesse sentido, destaca-se a importância da reflexão sobre o papel político dos IFsna construção do desenvolvimento inclusivo, integrador e cidadão. Será que o Instituto Federal representa, de fato, uma mudança, no sentido de romper com a lógica da educação profissional como reprodutora de determinado sistema social? A nova institucionalidade temse mostrado mais aberta às discussões e às políticas de desenvolvimento que também se ocupem daqueles que o capitalismo não absorve?

O arcabouço legal sinaliza para essa inflexão; necessário, contudo, analisar se, nas escolhas de currículo, na pesquisa e extensão, os objetivos dos IFs concretizam-se, sob risco de as propostas da educação profissional e tecnológica não escaparem das amarras do mercado e do exacerbado individualismo dele derivado, a guerra de todos contra todos e a perda da alteridade e da solidariedade sociais. Em última instância, sucumbem à fragmentação e àdimensão de sua totalidade.

O papel da educação profissional dos IFs e sua relação com o desenvolvimento emergem, portanto, sobre outras bases. Uma educação que tenha o trabalho como princípio educativo, mas que incorpore valores ético-políticos e conteúdo histórico-científico e artísticos que caracterizam a práxis humana e favorecem uma vida plena. Num mundo globalizado em que o conhecimento é poder, é necessário que a educação e o 
desenvolvimento caminhemnuma concepção ampla, que possibilite às classes trabalhadores não apenas o papel de mãos de obra, mas de sujeitos capazes de traçar suas trajetórias de vida pela apropriação da ciência, da tecnologia e da cultura, pilares que estão na base dos IFs.

Uma educação que possa vir a ser um campo de forças na defesa da transformação social e de um desenvolvimento, como diz Coraggio (2000c), não pode ser vista como resultado da competitividade, mas como condição dessa, para que possam existir expectativas de melhoras na qualidade de vida dos trabalhadores, o que não é independente da qualidade de vida de toda a população. E, nesse contexto, a EPT tem que ser edificada no âmbito da política pública, no direito de todos os sujeitos sociais serem protagonistas na produção da riqueza social.

Nas palavras de Coraggio (2000b), as políticas sociais devem ser transformadas em políticas socioeconômicas, cujo objetivo é o desenvolvimento a partir da sociedade. Nesse sentido, educação e desenvolvimento estariam em convergência, sendo o Estado o coordenador e o fomentador de políticas públicas.

Nesse ponto, é interessante relembrar o ideário neoliberal no governo FHC, com as políticas de privatização da formação profissionale, ao mesmo tempo, atransferência para o poder local da responsabilidade de prover e de promover o seu desenvolvimento, com o estímulo ao empreendedorismo, a partir de política de arranjos produtivos locais (APLs). Hasenclever e Fauré (2019, p.478), ao discutirem sobre os arranjos produtivos e locais, afirmam que "[...] as forças locais são relevantes para desenvolvimento, mas insuficientes para a promoção" e acrescentam dificuldades relevantes:

[...] as dificuldades institucionais de se promover desenvolvimento em uma economia federativa de estados e municípios, sem instâncias intermediárias (macrorregiões, microrregiões e regiões metropolitanas) para criar projetos conjuntos e unir forças no sentido de reduzir as desigualdades [...]. (HASENCLEVER; FAURÉ, 2019, p. 478).

Para os autores, dentre as razões para justificar o problema ou o pouco sucesso dessa política das APLs, está ofato de o país, dentro de um projeto desenvolvimentista, ter vivido um tempo largo de suaindustrialização(1930-1970) com políticas de desenvolvimentoe de fortalecimento das indústrias, com forte presença do Estadoe sobretudo com preocupação na redução das desigualdades regionais,com a implantação de grandes empreendimentos que se estabeleciam, porém, como enclaves, apartados da tradição local.

Desse modo, o Governo, na era FHC, ao optar por uma política neoliberal, de Estado Mínimo, que reservou para si apenas o papel de interferir na correção das distorções do 
Mercado, retira da agenda política a questão da redução das desigualdades até então vigente, mas não se encontrou nos estados e municípios, substratos suficientes para o sucesso dessas iniciativas e, nesse sentido, não se obteve o resultado esperado em se tratando dessa cultura do empreendedorismo e das APLs.Sobre esse debate, Brandão (2012, p. 183) é crítico em relação à ideia que "paira no ar" de que "[...] estaríamos vivendo em uma comunidade, não em sociedade", o que, temerosamente, poderia levar-nos a olhar o espaço social como ambiente harmônico, sem os conflitos inerentes ao sistema capitalista, fazendo crer na capacidade empreendedora e solidária de uma comunidade, colocando sobre ela a total responsabilidade pelo seu desenvolvimento. $\mathrm{O}$ autor ainda afirma a necessidade de se pensar em outras escalas para análise da dimensão espacial do desenvolvimento, em especial, a nacional. Ingenuidade é imaginar que uma região possa sozinha gerar um processo de desenvolvimento, sem levar em conta as condições estruturais externas. Harvey (1992) corrobora Brandão (2012) e reforça a ideia de que, para o sistema capitalista encontrar as condições de ordem para funcionar, é necessário que o Estado seja responsável pelas políticas macroeconômicas. Nesse sentido, o poder exclusivo do Estado Nação deve ser preservado como forma de estratégia de desenvolvimento, considerando a dimensão política que cabe exclusivamente à escala nacional.

Todas essas reflexões são importantes, uma vez que não há uma válida, ao contrário, todas são pertinentes. Assim, é necessário pensar as relaçõeseducação e trabalho eIFs e desenvolvimento local e regional como um desafio sob novas bases. É preciso também retomar esse sentido de proximidade com o local na compreensão dessarelação, numa métrica que comporta a cultura e as potencialidades locais e regionais, bem como as necessidades de formação das camadas populares em toda a sua diversidade, num processo social inclusivo pela educação e trabalho, numa dimensão espacial desse equipamento como instrumento de intervenção.

Numa sociedade globalizada em que os postos de trabalho se retraem e a distância entre os mais altos salários e os postos de trabalho menos remunerados se amplia, o debate a respeito da economia popular cresceu, em especial na América Latina, como uma alternativa distinta da economia capitalista hegemônica.

Mais uma vez, trazemos Coraggio (2000b), na defesa de outra economia, que possa criar pontes de passagem entre o modelo capitalista de produção e a economia popular e solidária. Considerando esse contexto atual de exclusão de massa da população dos postos de trabalho, esse tipo de economia tornou-se mais identificada como economia dos pobres, pela evidência de como os trabalhadores recorrem a ela como estratégia para a sua sobrevivência. 
Identificá-la como uma economia dos pobres, de certa maneira, parece suscitar a ideia de um desprestígio ou mesmo de ineficiência desse tipo de economia, o que poderia justificar a ação pouco expressiva de políticas públicas para essa demanda.

A exclusão de camadas da população ao trabalho digno e do acesso aos direitos fundamentais tem especial registro histórico na sociedade brasileira. A industrialização tardia, no Brasil, não trouxe consigo a preocupação de gerar o mercado de consumo interno e, nesse sentido, a remuneração também não foi pensada na perspectiva da reprodução social da massa trabalhadora. Compreende-se, por esse feito, que o crescimento das cidades não apresentou qualquer preocupação que não fosse o atendimento às necessidades das indústrias e do capital. Assim, nas franjas desses centros urbanos, ficam os trabalhadores que o capitalismo não absorve e nunca terá condições de fazê-lo, uma vez que, na produção capitalista, o avanço tecnológico e o princípio da economia/lucro quase nunca se compatibilizam com a defesa da ampliação de postos de trabalho e com a ampliação do bemestar social.

Mas, afinal, de que maneira essa nova institucionalidade, a de Instituto Federal, poderia trabalhar para essa nova economia, dentro de um sistema capitalista que nos aprisiona? Em suas propostas, o IFFluminenseestaria, efetivamente, atuando nesse sentido ou mantém-se no paradigma anterior? Que escolhas de atuação são vitoriosas?

Como o IF precisa compreender seu território para interferir em sua função social? Posicionar-se em função dos interesses que se identificam ou se referenciar como "magistrado", buscando um consenso? Que imagem os trabalhadores trazem da instituição? Quais são as impressões do mercado? Como a estrutura organizacional pode assegurar os diversos diálogos? Como a instituição dialoga com o poder público e com a sociedade?São questões que merecem respostas e que podem suscitar novos estudos.

\section{PERSPECTIVAS E AÇÕES DO IFFLUMINENSENO NORTE FLUMINENSE}

Os IFse a capilaridade alcançada pela expansão da Rede Federal, com a oferta pública e gratuita em locais até então desprovidos dessa modalidade educacional, reduziram as desigualdades de oportunidades ${ }^{10}$ educacionais no território brasileiro. Das 488 novas unidades, $94 \%$ estão fora das capitais, e $64 \%$ dos campi ficam em cidades com até 100.000

\footnotetext{
${ }^{10}$ Os Censos da Educação Superior de 2003 e de 2014 apresentam a evolução de matrículas nas graduações presenciais nosCEFETs/Institutos Federais, nesse período: no interior, foi de 531\%, enquanto, nas capitais, foi de $76 \%$. O Censo da Educação Básica não apresenta dados de matrícula para o interior e para a capital.
} 
habitantes (AQUINO, 2020), o que reforça a sua identidade com realidades marcadas por profunda desigualdade social e que vêm ao encontro do contexto social de grande parte dos municípios brasileiros. Em um país heterogêneo, diversificado e desigual como o Brasil, como afirma Bacelar (2013), essa penetração da Rede em regiões interioranas pode contribuir se articulada com outras políticas públicas, no longo prazo, para alterar esse quadro de desigualdades regionais.

Esse processo de interiorização da educação profissional e tecnológica também deve ser observado sob o ponto de vista do incremento em regiões não metropolitanas. $\mathrm{O}$ caso apresentado neste artigo sinaliza nessa direção. O IFFluminense está presente emquatro mesorregiões do estado do Rio de Janeiro (ERJ), como mostra a Figura 3,onde está destacado o território de atuação da instituição.

Com um olhar mais centrado na mesorregião Norte Fluminense, interior do ERJ, temos, historicamente, os municípios de Macaé e de Campos dos Goytacazes, que concentram a força econômica da região. Campos dos Goytacazes é um tradicional polo regional de comércio e serviços; seu dinamismo está relacionado com o Comércio Varejista e com o grande número de empregados na Administração Pública. No setor de Serviços, o destaque é para o setor educacional. O impacto das atividades de exploração e produção de petróleo e gás da Bacia de Campos faz-se sentir nas contas bancárias do município, pela sua condição debeneficiário das rendas petrolíferas,o que conferiu a adjetivação do município comopetrorrentista, sem o mesmo efeito sobre a dinâmica econômica.O município de Macaé tem seu dinamismo econômico atrelado às atividades de exploração e de produção de petróleo e gás,o que lhe confere a condição de maior empregador do interior do ERJ no setor de Serviços e o maior no setor Extrativo Mineral. Importante ressaltar a capacidade de arrasto das atividades petrolíferas sobre os setores econômicos de forma geral(SILVA NETO; ROCHA, 2014). Nesse contexto, aparece, mais recentemente, o município de São João Barra pela implantação do Porto do Açu.

Assim, analisando essa mesorregião sob a ótica da expansão da Rede Federal, o IFFluminense tem dois campido período pré-expansão11: Campos Centro (o chamado campus centenário), localizado em Campos dos Goytacazes, e o campus Macaé (inaugurado

\footnotetext{
${ }^{11}$ Os demais campi do IFFluminense localizam em outras regiões do território fluminense, a saber: no Noroeste Fluminense (NOF), o campus Itaperuna (inaugurado em 2010); o de Bom Jesus do Itabapoana (antigo Colégio Técnico Agrícola Ildefonso Bastos Borges, vinculado à Universidade Federal Fluminense); o campus Avançado Cambuci (inaugurado em 2012) e o campus Santo Antônio de Pádua (em 2015). Na Região da Baixadas Litorâneas, o campus Cabo Frio e na região Metropolitana do Rio de Janeiro, os campi Avançado de Maricá (2015) e de Itaboraí (em 2021).
} 
em 1993, como Unidade Descentralizada, no município de mesmo nome) e ainda duas experiências de oferta de cursos técnicos nos municípios de Quissamã e de São João da Barra, em parcerias com as prefeituras municipais. Na fase recente pós-expansão, o NF concentra o maior número de unidades do IFFluminense. Além dos dois campi, consolidou sua ação em Quissamã e em São João da Barra com a implantação de um campus em cada cidade, e ainda, o campusCampos Guarus (inaugurado em 2006, em bairro periférico da cidade de Campos dos Goytacazes), a Reitoria, um Polo de Inovação e o Centro de Referência em Tecnologia, Informação e Comunicação.

Figura 3 - Mapa do estado do Rio de Janeiro com as unidades do Instituto Federal

\section{Fluminense}

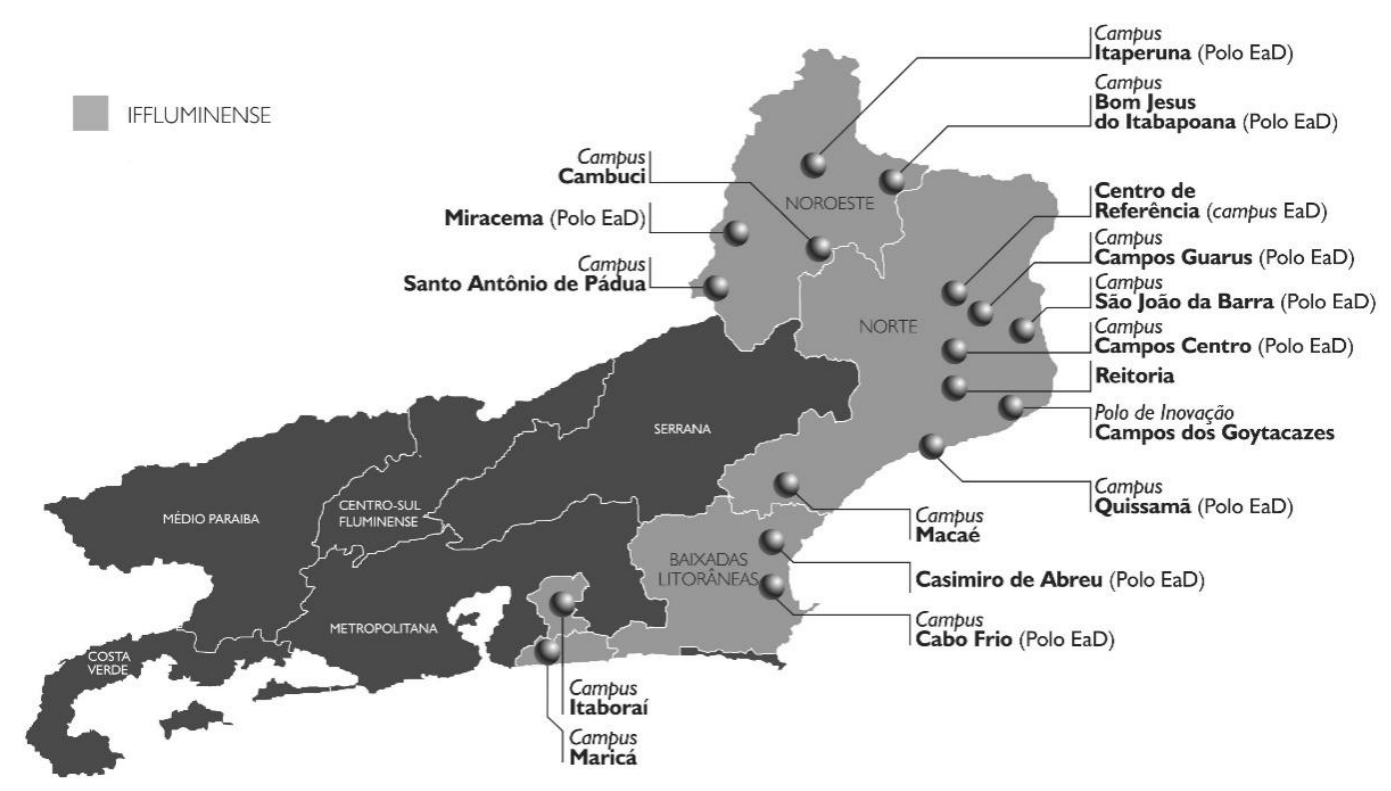

Fonte: Portal do IFFluminense. ${ }^{12}$

Existe, portanto, considerando a diversidade social e cultural e a diferenciação produtiva características dos municípios brasileiros, vários interiores no interior do território brasileiro. Os núcleos urbanos contemplados com grandes investimentos, como é o caso dos oriundos das atividades portuárias e de extração e produção de petróleo e gás, tendem a configurar as chamadas ilhas de prosperidade, do ponto de vista das interações com o seu

\footnotetext{
${ }^{12}$ Oscampi do IFFluminense que aparecem com a indicação de Polo EaD são unidades com oferta de cursos presenciais e também a distância.
} 
entorno territorial, urbano e econômico (CRUZ; TERRA, 2015). De um lado, os dinâmicos aglomerados "ilhados" e, de outro, o que sobra para a periferia, os que se encontram fora do raio de alcance dos benefícios das "ilhas dinâmicas", espalhadas por todo o país, e que demandam ações em direções e sentidos diferentes.E, principalmente esses, são territórios que dão sentido à presença de um Instituto Federal.

Pela Lei $n^{\circ}$. 11.892/2008, os IFstêm autonomia para atuar em todos os níveis e modalidades de ensino e na formação profissional e tecnológica. A característica relevante e singular, nesse desenho institucional, refere-se à verticalização da ofertada educação profissional, desde a educação básica à educação superior. Quevedo (2016, p. 100) comenta que essa verticalização não deve ser sinônimo apenas da oferta de cursos de uma mesma área, em diferentes níveis e modalidades, mas, como a própria autora destacou, esse tipo de oferta é "[...] condição para que a verticalidade aconteça" e, com esse entendimento,a "[...] concepção de verticalização é ainda mais ampla", ou seja, ela deve acontecer não apenas no ensino, mas na pesquisa e na extensão.

É evidente que se trata de uma estrutura complexa, seja pela formação dos profissionais, seja pela necessária flexibilização curricular nos itinerários de formação ou mesmo na integração entre os sujeitos de diferentes níveis de escolarização da educação profissional e tecnológica, nos diversos espaços de ensino e aprendizagem (QUEVEDO, 2016).

No presente artigo, ainda que reconheçamos que a ação educacional se multiplica e se transforma pela integração ensino, pesquisa e extensão, o recorte de análise que trazemos como variável é a oferta de cursos, por um período que corresponde ao movimento de expansão do IFFluminense no NF, em sua estrutura e função, relacionado à questão do território e à atuação local e regional.

O Quadro 1 mostra a evolução da oferta de cursos técnicos, numa proposta matricial em que se apresentam os eixos tecnológicos e as modalidades de ensino. Os dados referem-se a 2013 e 2020, período em que oIFFluminensejá apresentava a conformação atual (cinco campi) na região NF. Num balanço para o período, identificam-se ofertas que estão ativas nesse período e outras que não se encontram mais ativas. 
Quadro 1 - Oferta de curso técnico presencial por eixo tecnológico nos campi localizados na região Norte Fluminense - 2013/2020

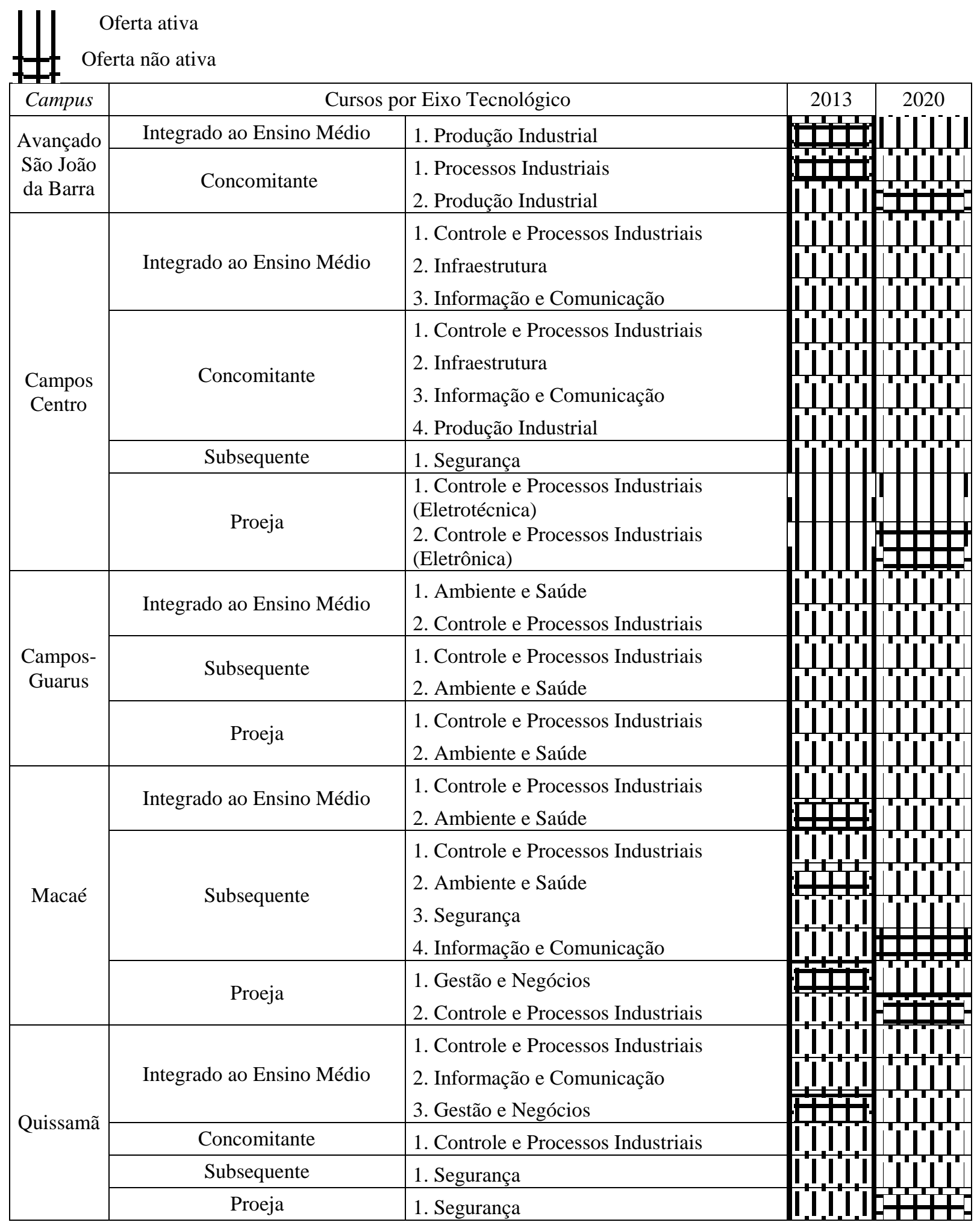

Fonte: Portal do IFFluminense e Catálogo Nacional de Cursos Técnicos (Resolução Conselho Nacional de Educação/MEC n ${ }^{\circ}$ 1/2014). 
Pelos dados, é possível verificar que a ampliação da oferta de cursos técnicos de nível médio (integrado, concomitante ou sequencial) ocorreu apenas em razão da expansão da implantação de campina fase pós-expansão. Em relação ao perfil dos cursos, o destaque especial para o campus Campos Guarus, que inaugurou a oferta de cursos técnicos nos eixos tecnológicos de Ambiente e Saúde e de Gestão e Negócios, sendo o único campus do IFFluminensecom uma resposta à região que não dispunha de educação pública para a formação emEnfermagem, Farmáciae Meio Ambiente.

NoscampiCampos Centroe Macaé,a prioridade da oferta continua sendo nos eixos tecnológicos relacionados à indústria, expertise dessescampi,pelaprópria trajetória histórica, e, em especial, pela relação da instituição com a formação de profissionais técnicos, considerando os grandes investimentos da Petrobras e de empresas internacionais do ramo na exploração e na produção de petróleo e gás, na Bacia de Campos. Esses dois campi são os pré-expansão, cuja oferta na área industrial sempre foi a referência. É o efeito do práticoinerte que Santos (2006) usa para explicar as heranças que processos sociais sempre legam e que se fazem presentes nas etapas futuras.

Um dado contraditório é a retração dos cursos na modalidade Proeja(Art. $7^{\circ}$, inciso I, da Lein ${ }^{\circ}$ 11.892/2008). À exceção do campus Campos Guarus, que mantém sua oferta, o campusQuissamã extinguiu a oferta e o campusCampos Centro, que, em tese seria o que apresenta maior expertise no eixo tecnológico (indústria) e que teria representatividade para avançar na oferta do Proeja, reduziu-os. E o contraditório, na interpretação dos autores, é porque a integração é uma questão que está no centro das mudanças vindas com os IFs, inclusive, é uma prerrogativa legal que unifica as diversas representações, sejam elas ligadas diretamente às instituições da Rede Federal ou aquelas ligadas à academia,o que amplia a coesão em defesa da Rede Federal de Educação Profissional eTecnológica.

A Tabela 2 apresenta a participação percentual das modalidades dos cursos técnicos na oferta dos campi em estudo. Esses dados são importantes, uma vez que, na Lei de criação dos IFs, há um claro posicionamento em favor do ensino técnico integrado. No Art. $7^{\circ}$, lê-se que esses cursos devem ser "[...] preferencialmente na forma de cursos integrados, para os concluintes do ensino fundamental e para o público da educação de jovens e adultos." (BRASIL, 2008). Essa recomendação é reforçada no Art. $8^{\circ}$, que garante o mínimo de 50\% (cinquenta por cento) das vagas dos cursos ofertados pelosIFs para os cursos técnicos e, prioritariamente, para cursos técnicos integrados, para os concluintes do ensino fundamental e para o público da educação de jovens e adultos. 
Interessanteque não haveria necessidade de utilizar essa condicionante para os concluintes do ensino fundamental, uma vez que esse já é um requisito de acesso previsto nas diretrizes da educação nacional, mas esse pleonasmo pode sugerir a reafirmação da intencionalidade na Lei,no sentido da romper com a oferta de cursos concomitantes que, em tese, representam uma cisão entre a ciência e a técnica, educação geral e educação profissional, uma separação artificial e indefensável para a concepção dos IFs. Na outra especificação, para o público da educação de jovens e adultos, também se torna evidente o compromisso dos IFs com osjovens e adultos trabalhadores que não puderam permanecer na escola ou que não tiveram acesso a ela no período mais aconselhável por Lei, portanto, uma evidenteopção política do Estado no sentido da formação profissional e tecnológica das camadas menos favorecidas da população.

Assim, é possível confirmar que a oferta decursos técnicos integradosde nível médio é predominante em todos oscampi.Em relação ao Proeja, não registramos expressividade na oferta, haja vista que, no campusCampos Centro, esses cursos representam apenas 3,5\% do total ofertado; em Macaé, 9,9\%, e, em Guarus,27,3\%, sendo esse o índice mais alto.Considerando o público de jovens e adultos, os cursos técnicos subsequentes poderiamganhar relevância como oportunidade para a educação continuada e em serviço. A oferta de cursos técnicos, na modalidade concomitante, ainda é resiliente, em especial nocampusCampos Centro, talvez por manter a articulação com escolas da rede pública e pela adoção da política de $\operatorname{cotas}^{13}$, apesar da clara intenção no texto da Lei,no sentido da priorização da oferta dos cursos técnicos integrados ao ensino médio.A Tabela 2 e o Quadro 3 apresentam uma síntese da oferta de cursos técnicos nas diferentes modalidades.

\footnotetext{
${ }^{13}$ A Lei $n^{\circ} 12.711 / 2012$ conhecida como a Lei de Cotas e regulamentada pelo Decreto $n^{\circ} 7.824 / 2012$ dispõe sobre o ingresso nas universidades federais e nos institutos federais, sendo que nos Institutos alcançam o ensino superior e o ensino técnico. A distribuição das cotas é feita da seguinte forma: para o ingresso no ensino superior, as instituições federais de educação superior vinculadas ao Ministério da Educação reservarão, em cada concurso seletivo para ingresso nos cursos de graduação, por curso e turno, no mínimo $50 \%$ de suas vagas para estudantes que tenham cursado integralmente o ensino médio em escolas públicas e no preenchimento dessas vagas, $50 \%$ deverão ser reservados aos estudantes oriundos de famílias com renda igual ou inferior a 1,5 salário-mínimo per capita. E sobre as vagas destinadas aos estudantes que tenham cursado integralmente o ensino médio em escolas públicas, serão aplicadas um percentual de reserva de vagas que será preenchida, por curso e turno, por autodeclarados pretos, pardos e indígenas e por pessoas com deficiência, nos termos da legislação, em proporção ao total de vagas no mínimo igual à proporção respectiva de pretos, pardos, indígenas e pessoas com deficiência na população da unidade da Federação onde está instalada a instituição, segundo o último censo da Fundação Instituto Brasileiro de Geografia e Estatística - IBGE. No caso das vagas ofertadas pelas instituições federais de ensino técnico de nível médio segue a mesma metodologia adotada para o ensino superior. O IFFluminense, por meio da Resolução $n^{\circ}$ 23/2012, adotou a reserva de $25 \%$ na oferta de vagas para os cursos de graduação e a reserva de 50\% na oferta de vagas para os cursos técnicos de nível médio.
} 
Quadro 2 - Oferta de vagas por modalidades de curso técnico, nos campido IFFluminense localizados na região Norte Fluminense, $1^{\circ}$ semestre/2020

\begin{tabular}{l|c|c|c|c|c|c|c|c|c|r}
\hline \multirow{2}{*}{ Modalidade } & \multicolumn{2}{|c|}{ SJBarra } & \multicolumn{2}{c|}{$\begin{array}{c}\text { Campos } \\
\text { Centro }\end{array}$} & \multicolumn{2}{c|}{$\begin{array}{c}\text { Campos } \\
\text { Guarus }\end{array}$} & \multicolumn{2}{c|}{ Macaé } & \multicolumn{2}{c}{ Quissamã } \\
\cline { 2 - 13 } & $\mathrm{N}^{\circ}$ & $\%$ & $\mathrm{~N}^{\circ}$ & $\%$ & $\mathrm{~N}^{\circ}$ & $\%$ & $\mathrm{~N}^{\circ}$ & $\%$ & $\mathrm{~N}^{\circ}$ & $\%$ \\
\hline Integrado ao Ensino & 60 & 66,7 & 320 & 44,4 & 120 & 43,6 & 210 & 46,2 & 100 & 55,6 \\
Médio & 30 & 33,3 & 340 & 47,2 & 0 & 0,0 & 0 & 0,0 & 40 & 22,2 \\
Concomitante & 0 & 0 & 35 & 4,9 & 80 & 29,1 & 200 & 44,0 & 40 & 22,2 \\
Subsequente & 0 & 0 & 25 & 3,5 & 75 & 27,3 & 45 & 9,9 & 0 & 0,0 \\
Proeja & 90 & 100,0 & 720 & 100,0 & 275 & 100,0 & 455 & 100 & 180 & 100,0 \\
\hline Total & & & & & & & & & &
\end{tabular}

Fonte: Portal do IFFluminense.

Por outro lado, é sensível a ampliação do ensino superior, que quase triplicou no campus Campos Centro (cinco cursos em 2014 e 14 cursos em 2020) e duplicou nos campi Macaé e Campos Guarus (ambos atualmente com dois cursos), o que pode ser compreendido pela opção do IFFluminense em se consolidar como instituição de ensino superior. As licenciaturas, que já se implantavam desde 2000, na área das Ciências Exatas, alcançam hoje todas as disciplinas do ensino médio, visível compromisso dos IFs com a melhoria da educação básica. As engenharias crescem prioritariamente no campus Centro e absorvem, em certa medida, os cursos superiores de tecnologia voltados para a indústria, como mostrao Quadro 3.

Quadro 3 - Oferta de curso superior presencial nos campi localizados na região Norte Fluminense - 2014/2020

\begin{tabular}{|c|l|l|l|} 
U1 Oferta ativa \\
Oferta não ativa
\end{tabular}




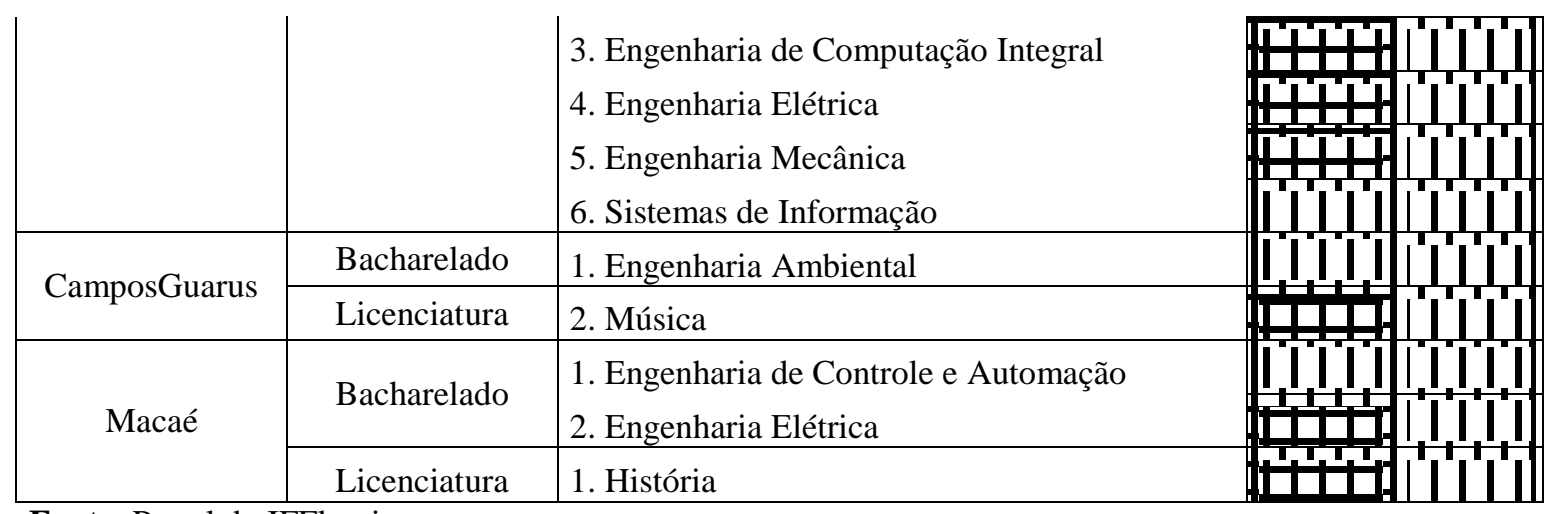

Fonte: Portal do IFFluminense.

Além da questão da oferta como foco de análise, há outros temas que devem ser aprofundados, como a verticalização da educação que, em nossa análise,cumpre-se com a ampliação da oferta na pós-graduação, com cursos de pós-graduação lato e stricto sensu (mestrado), com destaque para o mestrado profissional, sendo o primeiro deles implantado, em 2006, na área de Sistemas Aplicados à Engenharia e Gestão, numa iniciativa multicampiCampos Centro e Macaé. A partir de 2014, gradativamente passaram a ser ofertados os mestrados em Engenharia Ambiental, de Ensino de Física, de Ensino e suas Tecnologias e de Modelagem e Tecnologia para Meio Ambiente Aplicadas em Recursos Hídricos.

Em relação aos cursos de formação inicial e continuada de trabalhadores, objetivando a capacitação, o aperfeiçoamento, a especialização e a atualização de profissionais, em todos os níveis de escolaridade, nas áreas da educação profissional e tecnológica (Art. $7^{\circ}, \S I I$, Lei $n^{\circ}$ 11.892/2008), não obtivemos dados suficientes que possibilitassem uma avaliação. Em relação às atividades de extensão com comunidades, a exemplo das comunidades da pesca, a instituição desenvolveu uma ação importante de formação com as colônias de pesca, no período de fomento às políticas públicas em favor das minorias (2004-2014). A criação do Centro de Referência em Tecnologia, Informação e Comunicaçãoé outro recurso para a oferta cursos de formação profissional de nível básico e técnico de educação profissional e tecnológica e para atualização continuada de professores na modalidade $\mathrm{EaD}$ ou presencial. Nessa linha, podemos destacar oPrograma de Qualificação de Professores para EaD e o Curso de Formação Continuada em Metodologias Ativas de Ensino.

A trajetória institucional, o diálogo com pesquisadores como Santos (2018), Frigotto, Ciavatta e Ramos (2008) Pereira (2020), Hasenclever e Fauré (2019), Coraggio (2000) e a experiência vivida na instituição nos permitem admitir que o IFFluminense, como equipamento público integrante da rede federal de educação profissional, científica e tecnológica, de fato, tem a sua imagem institucional consolidada na região como locus da 
educação profissional, científica e tecnológica, principalmente no que se refere aos cursos técnicos de nível médio e de ensino superior. No entanto a compreensão a respeito da autonomia dessa nova institucionalidade ainda é difusa, e essa talvez seja uma das dificuldades para uma ação mais efetiva na formação profissional de nível básico dos trabalhadores, explícita na Lei $n^{\circ} 11.892 / 2008$ de criação dos IFs, junto às iniciativas da sociedade civil, completando assim o seu escopo, considerando ensino, pesquisa e extensão. É justa, porém, a observação de que a velocidade com que se deu o processo de expansão da rede federal e do IFFluminense ainda não permite uma análise mais substantiva. As vias de diálogo com a sociedade sinalizam para uma ação institucional sensível à escuta da sociedade. Esse estudo, portanto, mais que uma análise até o momento atual, é um convite para o debate permaneça em aberto.

\section{NOTAS CONCLUSIVAS}

É inquestionável o crescimento exponencial do IFFluminense na última década e sua disposição em firmar a sua imagem dentro das finalidades e dos objetivos previstos para os IFs, no território onde estão presentes, ainda que, numa primeira leitura, a instituição pareça manter-se com propostas de formação dentro do paradigma hegemônico das ciências e da produção. O desafio, porém, vai além da possibilidade de oferta, tendo de se mostrar como opção de acesso paraa clientela. O mundo passa por mudanças profundas, e o quadro é de crise, em especial a crise do petróleo, com consequências negativas na região e cada vez mais instabilidade nos postos de trabalho. No País, em especial, o desemprego alcança 14 milhões de pessoas da faixa etária economicamente ativa. As políticas neoliberais do atual governo avançam no sentido de maior fragilização no que se refere aos direitos dos trabalhadores. A educação profissional e tecnológica pode se firmar como uma trincheira de resistência para as camadas populares. Somado às medidas de inclusão respaldadas em Lei, a exemplo da política de cotas, formas de acesso e outras, é possível aguçar o olhar também na direção de uma educaçãoprofissional técnica e tecnológicarevestida de saberes que permitamaos cidadãos empreender a sua produção e reprodução da vida sobre outras bases, a exemplo da economia solidária e popular, defendida em Coraggio (2000b). Não existe caminho único, apesar de o discurso hegemônico apontar apenas para um ideário. Acreditamos que é possível ativar outras vias para a subsistência quando se pensa em redução da desigualdade imoral que assola grande fatia da população, dentro de uma concepção freiriana de uma educação que 
transforma eliberta e, portanto, concorre para uma sociedademais igualitária, mais fraterna, mais feliz e democrática.

\section{REFERÊNCIAS}

AQUINO. Carla N. P. Educação e efeito vizinhança: uma análise a partir dos Institutos Federais de Educação, Ciência e Tecnologia. Tese (Doutorado em Planejamento Regional e Gestão de Cidades) - Universidade Candido Mendes, Campos dos Goytacazes, 2020.

BACELAR, Tânia. Tendências do Desenvolvimento Regional recente no Brasil. In: BRANDÃO, C.A.; SIQUEIRA, H. (Orgs.). Pacto Federativo, integração nacional e desenvolvimento regional. São Paulo: Editora da Fundação Perseu Abramo, 2013. p. 39-51.

BRANDÃO, C.A. A reafirmação do nacional e as possibilidades de estratégias e políticas de desenvolvimento e suas escalas espaciais. In: BRANDÃO, C.A. Território e desenvolvimento: as múltiplas escalas entre o local e o global. 2. ed. Campinas: Editora da UNICAMP, 2012. cap. 5.

BRASIL. Decreto ${ }^{\circ} 7.566$, de 23 de setembro de 1909. Cria nas capitais dos Estados da República Escolas de Aprendizes Artífices, para o ensino profissional primário e gratuito.Diário Oficial da União, Brasília, DF, 26 set. 1909.

BRASIL. Decreto-Lei $n^{\circ} 4.073$, de 30 de janeiro de 1942. Lei orgânica do ensino industrial. Diário Oficial da União, Brasília, DF, 9 fev. 1942.

BRASIL. Lei ${ }^{\circ}$ 3.552, de 16 de fevereiro de 1959. Dispõe sobre nova organização escolar e administrativa dos estabelecimentos de ensino industrial do Ministério da Educação e Cultura, e dá outras providências. Diário Oficial da União, Brasília, DF, 17 fev. 1959.

BRASIL. Lei $n^{\circ} 5.692$, de 11 de agosto de 1971. Fixa Diretrizes e Bases para o ensino de $1^{\circ} \mathrm{e}$ $2^{\circ}$ graus, e dá outras providências.Diário Oficial da União, Brasília, DF, 12 ago. 1961.

BRASIL. Lei no 4.024, de 20 de dezembro de 1961. Fixa as Diretrizes e Bases da Educação Nacional.Diário Oficial da União, Brasília, DF, 21dez. 1961.

BRASIL. Lei $\mathrm{n}^{\circ}$ 7.044, de 18 de outubro de 1982. Altera dispositivos da Lei $\mathrm{n}^{\circ}$ 5.692, de 11 de agosto de 1971, referentes a profissionalização do ensino de $2^{\circ}$ grau.Diário Oficial da União, Brasília, DF, 19out. 1982.

BRASIL. Lei $\mathrm{n}^{\circ}$ 8.948, de 08 de dezembro de 1994. Dispõe sobre a instituição do Sistema Nacional de Educação Tecnológica e dá outras providências. Diário Oficial da União, Brasília, DF, 9 dez. 1994. 
BRASIL. Lei $\mathrm{n}^{\circ}$ 9.394, de 20 de dezembro de 1996. Estabelece as diretrizes e bases da educação nacional. Diário Oficial da União, Brasília, DF, 23 dez. 1996.

BRASIL. Decreto $\mathrm{n}^{\circ} 2.208$, de 17 de abril de 1997. Regulamenta o $§ 2^{\circ}$ do Art. 36 e os arts. 39 a 42 da Lei no 9.394, de 20 de dezembro de 1996, que estabelece as diretrizes e bases da educação nacional. Diário Oficial da União, Brasília, DF, 18 abr. 1997.

BRASIL. Lei n ${ }^{\circ}$ 9.649, de 27 de mai. de 1998. Dispõe sobre a organização da Presidência da República e dos Ministérios, e dá outras providências. Poder Executivo, Brasília, DF.Diário Oficial da União, Brasília, DF, 27 maio 1998.

BRASIL. Lei ${ }^{\circ}$ 11.892, de 29 de dezembro de 2008. Institui a Rede Federal de Educação Profissional, Científica e Tecnológica, cria os Institutos Federais de Educação, Ciência e Tecnologia, e dá outras providências. Diário Oficial da União, Brasília, DF, 30 dez. 2008.

CIAVATTA, Maria; RAMOS, Marise Nogueira; FRIGOTTO, Gaudêncio. Educação Profissional e Desenvolvimento. Revista Pedagogia Cotidiano Ressignificado, São Luís, v. 2, p. 39-62, 2008.

CRUZ, José Luis Vianna da.; TERRA, Denise Cunha Tavares. Indústria extrativa petrolífera Fluminense e limites ao desenvolvimento regional. In: SEMINÁRIO INTERNACIONAL SOBRE DESENVOLVIMENTO REGIONAL,7., 2015, Santa Cruz do Sul, RS. Anais [...]. Santa Cruz do Sul, RS:UNICS, 2015.

FONTES, V. Reflexões im-pertinentes:história e capitalismo contemporâneo. Rio de Janeiro: Bom Texto, 2005.

CORAGGIO, José Luís. Propostas do Banco Mundial para a educação: sentido oculto ou problemas de concepção? In: TOMMASI, Livia; WARDE, Mirian Jorge; HADDAD, Sérgio (org.). O Banco Mundial e as políticas educacionais. 3. ed. São Paulo: Cortez, 2000a, p. 75-124.

CORAGGIO, José Luís. A economia dos setores populares à economia do trabalho. In: COSTA, Francisco Lara Beatriz; KRAYCHETE, Gabriel (org.).Economia dos setores populares: entre a realidade e a utopia. Petrópolis, RJ: Vozes, $2000 \mathrm{~b}$.

CORAGGIO, José Luís. Desenvolvimento humano e educação: o papel das ONGs latinoamericanas na iniciativa da educação para todos. 3. ed. São Paulo: Cortez, 2000c.

FRIGOTTO, Gaudêncio; CIAVATTA, Maria. Educar o trabalhador cidadão produtivo ou o ser humano emancipado? Trabalho, Educação e Saúde, Rio de Janeiro, v. 1, n. 1, p.45-60, 2003.

HARVEY, D.A. A transformação político-econômica do capitalismo do final do século XX. In: HARVEY, D.A. Condição pós-moderna. São Paulo: Loyola, 1992. p. 115-184. 
HASENCLEVER, Lia; FAURÉ, Yves, A. Limites dos arranjos produtivos locais: Macaé no cenário de reconfiguração da cadeia do petróleo e gás. In:SILVA, S. R. de A.;CARVALHO, M. R. (org.).Macaé, do caos ao conhecimento: olhares sobre o cenário de crise econômica. Macaé: Prefeitura de Municipal de Macaé, 2019.

IANNI, O. Estado e planejamento econômico no Brasil:1930-1970. Rio de Janeiro: Civilização Brasileira, 1971.

MÉSZÁROS, I. A Crise Estrutural do Capital. São Paulo: Boitempo, 2009.

MOSCOVICI, Serge. Representação social da Psicanálise. Rio de Janeiro: Zahar Editores, 2012.

PEREIRA, Luiz A. C. O Instituto Federal Fluminense no Desenvolvimento da Região Norte do Estado do Rio de Janeiro: o que pensam agentes estabelecidos no território. Tese (Doutorado em Planejamento Regional e Gestão da Cidade) - Universidade Candido Mendes, Campos dos Goytacazes, 2020.

QUEVEDO, Margarete de. Verticalização nos Institutos Federais de Educação, Ciência e Tecnologia: concepções e desafios no IFRS. Dissertação (Mestrado em Educação) Universidade de Caxias do Sul, Caxias do Sul, 2016. Disponível em: https://repositorio.ucs.br/xmlui/bitstream/handle/11338/1155/Dissertacao\%20Margarete\%20d e\%20Quevedo.pdf? sequence=1\&isAllowed=y. Acesso em: 03 jan.2020.

SANTOS, Boaventura de Sousa. Da ideia de universidade à universidade de ideias. In:

SANTOS, Boaventura de Sousa. Pela mão de Alice:o social e o político na pósmodernidade. 2.ed. São Paulo: Cortez, 1996, p. 187-234.

SANTOS, Jailson Alves dos. Política de expansão da RFEPCT: quais as perspectivas para a nova territorialidade e institucionalidade? In: FRIGOTTO, Gaudêncio (org.). Institutos Federais de Educação, Ciência e Tecnologia: relação com o ensino médio integrado e o projeto societário de desenvolvimento. Rio de Janeiro: UERJ, LPP, 2018. p. 113-124.

SANTOS, Milton. Da diversificação da natureza à divisão territorial. In:SANTOS, Milton. A natureza do espaço: técnica e tempo, razão e emoção. 4.ed. São Paulo: Editora da Universidade de São Paulo, 2006. p. 84-92.

SILVA NETO, Romeu; ROCHA, Maria das Dores. Avaliação dos impactos dos grandes projetos de investimentos na dinâmica do emprego formal no estado do Rio de Janeiro. $\begin{array}{lllllll}\text { Espaço eEconomia, } & \text { ano } & 3, & \text { n. } & 5, & 2014 .\end{array}$ 